\title{
Disruption of LDL but not VLDL clearance in autosomal recessive hypercholesterolemia
}

\author{
Christopher Jones, ${ }^{1}$ Rita Garuti, ${ }^{1}$ Peter Michaely, ${ }^{2}$ Wei-Ping Li, ${ }^{2}$ Nobuyo Maeda, ${ }^{3}$ \\ Jonathan C. Cohen, ${ }^{4}$ Joachim Herz, ${ }^{1}$ and Helen H. Hobbs ${ }^{1,5}$ \\ ${ }^{1}$ Department of Molecular Genetics and ${ }^{2}$ Department of Cell Biology, University of Texas Southwestern Medical Center, Dallas, Texas, USA \\ ${ }^{3}$ Department of Pathology and Laboratory Medicine, The University of North Carolina at Chapel Hill, Chapel Hill, North Carolina, USA. \\ ${ }^{4}$ Center for Human Nutrition and ${ }^{5}$ Howard Hughes Medical Institute, University of Texas Southwestern Medical Center, Dallas, Texas, USA.
}

\begin{abstract}
Genetic defects in LDL clearance result in severe hypercholesterolemia and premature atherosclerosis. Mutations in the LDL receptor (LDLR) cause familial hypercholesterolemia (FH), the most severe form of genetic hypercholesterolemia. A phenocopy of $\mathrm{FH}$, autosomal recessive hypercholesterolemia (ARH), is due to mutations in an adaptor protein involved in LDLR internalization. Despite comparable reductions in LDL clearance rates, plasma LDL levels are substantially lower in ARH than in FH. To determine the metabolic basis for this difference, we examined the synthesis and catabolism of VLDL in murine models of FH $\left(\mathrm{Ldlr}^{-/-}\right)$and ARH $\left(A r b^{-/-}\right)$. The hyperlipidemic response to a high-sucrose diet was greatly attenuated in $\mathrm{Arh}^{-/-}$mice compared with $\mathrm{Ldlr}^{-/-}$mice despite similar rates of VLDL secretion. The rate of VLDL clearance was significantly higher in $A r b^{-/-}$mice than in $\mathrm{Ldll}^{-/-}$mice, suggesting that LDLR-dependent uptake of VLDL is maintained in the absence of ARH. Consistent with these findings, hepatocytes from $\mathrm{Arb}^{-/-}$mice (but not $\mathrm{Ldlr}^{-/-}$mice) internalized $\beta$-migrating VLDL ( $\beta$-VLDL). These results demonstrate that ARH is not required for LDLR-dependent uptake of VLDL by the liver. The preservation of VLDL remnant clearance attenuates the phenotype of ARH and likely contributes to greater responsiveness to statins in ARH compared with FH.
\end{abstract}

\section{Introduction}

The LDL receptor (LDLR) plays a central role in coordinating the trafficking of circulating cholesterol by mediating the uptake of LDL, the major cholesterol-carrying lipoprotein. Mutations in LDLR cause familial hypercholesterolemia (FH), an autosomal dominant disorder characterized by severe hypercholesterolemia and premature coronary atherosclerosis (1). Individuals with 2 mutant LDLR alleles (FH homozygotes) often develop symptomatic heart disease in childhood (1). In 1973, Khachadurian and Uthman described a Lebanese family with an autosomal recessive form of severe hypercholesterolemia that was clinically indistinguishable from FH (2). Subsequently, patients with a similar phenotype were identified in England (3), Sardinia (4), and Japan (5), and the disease was named autosomal recessive bypercholesterolemia (ARH). Garcia et al. (6) used linkage analysis to identify the causative gene, $A R H$, which encodes an adaptor protein called ARH (also known as the LDLR adaptor protein) that couples the LDLR to the endocytic machinery (7-9).

The N-terminal portion of ARH contains a phosphotyrosine-binding (PTB) domain that binds to the internalization sequence (FDNPVY) in the cytoplasmic tail of the $\operatorname{LDLR}(7,8)$ and with phosphoinositides (8), which may link the protein to

Nonstandard abbreviations used: $\mathrm{ARH}$, autosomal recessive hypercholesterolemia; DiI, 1,1'-dioctadecyl-3,3,3',3'-tetramethylindocarbocyanine perchlorate; FCR, fractional catabolic rate; FH, familial hypercholesterolemia; FPLC, fast-performance liquid chromatography; LDL-C, LDL cholesterol; LDLR, LDL receptor; LRP, LDLR-related protein; PFA, paraformaldehyde; PMCA-O, 3-pyrenemethyl-23, 24dinor-5-cholen-22-oate-3 beta-yl oleate; PTB, phosphotyrosine binding; $\beta$-VLDL, $\beta$-migrating VLDL

Conflict of interest: The authors have declared that no conflict of interest exists. Citation for this article: J. Clin. Invest. 117:165-174 (2007). doi:10.1172/JCI29415. membrane lipids. The $\mathrm{C}$ terminal portion of ARH binds 2 of the major structural components of the clathrin-coated pit: clathrin and AP-2 $(7,8)$. The interaction with clathrin is mediated by a canonical clathrin box motif (LLDLE) that binds the terminal domain of the heavy chain of clathrin $(7,8)$. A second, highly conserved motif in the $C$ terminal region binds the $\beta_{2}$-adaptin subunit of AP-2 (7-9). The AP-2-binding motif in ARH does not share obvious homology with other $\beta_{2}$-adaptin-binding proteins, but mutagenesis studies suggest that ARH and the arrestin proteins bind to the same site on the appendage domain of $\beta_{2}$-adaptin (10). These studies are consistent with a model in which ARH couples the LDLR to the endocytic machinery. The model is supported by the observation that the PTB domain and either the clathrin box or the AP-2 binding site of ARH are required for clustering and internalization of the LDLR (11).

LDL turnover studies have demonstrated that the rate of clearance of LDL from the circulation is similar in subjects with ARH and in subjects lacking functional LDLRs (FH homozygotes) $(5,12)$, suggesting that ARH is essential for LDLR-mediated uptake of LDL. Despite comparable reductions in the fractional catabolic rate (FCR) of LDL, the metabolic and clinical phenotype of ARH tends to be less severe than that of FH (1-4, 12-18); plasma levels of LDL are lower and the onset of coronary artery disease is usually later in ARH subjects than in $\mathrm{FH}$ homozygotes. ARH patients also respond to lipid-lowering agents with a greater reduction in plasma levels of LDL than is typically observed in patients with homozygous FH.

The molecular basis for the less severe clinical phenotype in ARH is not known and is the subject of this paper. The finding that the rates of clearance of LDL are similarly depressed in ARH and FH subjects implicates the LDL production pathway. LDL is produced 
Table 1

Lipid levels in plasma and livers of mice fed a high-sucrose diet

\begin{tabular}{lcccc} 
& \multicolumn{2}{c}{ Plasma $(\mathrm{mg} / \mathrm{dl})$} & \multicolumn{2}{c}{ Liver $(\mathrm{mg} / \mathbf{g})$} \\
Genotype & Cholesterol & Triglycerides & Cholesterol & Triglycerides \\
Wild type & $102.7 \pm 8.7$ & $75.0 \pm 6.8$ & $5.54 \pm 1.26$ & $31.6 \pm 5.5$ \\
Arh $h^{+-}$ & $106.1 \pm 4.6$ & $77.2 \pm 3.4$ & $5.95 \pm 1.26$ & $33.7 \pm 9.1$ \\
Arh $^{-/}$ & $301.0 \pm 33.9$ & $101.2 \pm 12.3$ & $6.31 \pm 1.26$ & $26.8 \pm 6.0$ \\
Ldlr $^{-/}$ & $1147.8 \pm 214.0$ & $208.1 \pm 13.8$ & $8.97 \pm 1.19$ & $27.2 \pm 0.8$ \\
\hline
\end{tabular}

Mice (6 per group) consumed a diet (960237; MP Biomedicals) containing 60.2\% sucrose, $20 \%$ casein, $15 \%$ cellulose, $0.3 \%$ DL-methionine, $3.5 \%$ minerals and vitamins, and less than $0.2 \%$ fat for 6 weeks. Means \pm SD are shown.

as a metabolic by-product of VLDL, a triglyceride-rich lipoprotein produced exclusively by the liver. VLDL contains a single copy of apoB100 and multiple copies of a much smaller apolipoprotein, apoE. Circulating VLDL undergoes lipolysis to form VLDL remnants (also referred to as intermediate-density lipoproteins). VLDL remnants are cleared from the circulation by binding to hepatic LDLR via apoE rather than apoB. apoE binds the LDLR with a higher affinity than does apoB100 (19). Subjects with ARH may have a lower plasma level of LDL cholesterol (LDL-C) due to increased removal of VLDL remnants from the circulation. Alternatively, subjects with ARH may produce fewer VLDL particles, resulting in a lower rate of production of LDL.

To address these questions, we examined the metabolism of VLDL, VLDL remnants, and LDL using mice in which ARH was inactivated ( $\mathrm{Arb}^{-1-}$ mice) (20). These mice share many of the characteristics of humans with ARH. The FCR of radiolabeled LDL in the $\mathrm{Arb}^{-/-}$mice is as low as that of mice lacking LDLR $\left(\mathrm{Ldll}^{-/-}\right.$ mice) (20). Despite the very low rate of clearance of LDL in the $\mathrm{Arb}^{-1-}$ mice, the plasma levels of cholesterol on a chow diet are only modestly elevated compared with those of wild-type animals. Only when the $\mathrm{Arb}^{-/-}$mice consume a high-cholesterol diet does plasma cholesterol attain the same levels as seen in the $L d l^{\prime /}$ - animals (20). Here we show that LDLR-mediated clearance of VLDL is preserved both in vivo in ARH-deficient mice and in cultured hepatocytes from these animals. Thus, ARH is required for LDLR-dependent uptake of LDL but not VLDL in the liver.

\section{Results}

$\mathrm{Arb}^{-1-}$ mice are protected from sucrose-induced bypercholesterolemia and hypertriglyceridemia. Previously we showed that the rate of LDL clearance is reduced to similar low levels in chow-fed $\mathrm{Arb}^{-/-}$ mice and $\mathrm{Ldll}^{-/}$mice (20). Despite similar rates of fractional LDL clearance in the 2 strains, plasma levels of cholesterol (20) and apoB (Supplemental Figure 1; supplemental material available online with this article; doi:10.1172/JCI29415DS1) were

\section{Figure 1}

Plasma cholesterol and triglyceride levels $(\mathbf{A})$ and lipoprotein cholesterol levels (B) in sucrose-fed wild-type, $\mathrm{Ldll}^{-/-}, \mathrm{Arh}^{+/-}$, and $\mathrm{Arh} \mathrm{H}^{-/}$mice. Male $\mathrm{Arh}^{-/}$, $\mathrm{Arh} \mathrm{H}^{+-}$, and wild-type littermates, ages 16-18 weeks, and age-matched $L d l r^{-1}$ mice ( $n=6$ per genotype) were fed a high-sucrose diet for 6 weeks. Mice were sacrificed and blood was drawn from the inferior vena cava. Individual plasma cholesterol and triglyceride levels (A) were measured as described in Methods, and the means \pm SEM are given. (B) Aliquots of plasma from the animals in each group were pooled and size fractionated by FPLC. The cholesterol content of each fraction was measured as described (39). significantly lower in chow-fed $\mathrm{Arb}^{-/-}$mice than in $L_{d l r^{-1}}$ mice. To determine whether the lower plasma cholesterol levels of the $\mathrm{Arb}^{-/-}$mice were due to differences in VLDL metabolism, we examined the effect of increasing VLDL synthesis on plasma lipid levels by challenging $\mathrm{Arb}^{-/}, \mathrm{Arb}^{+/-}, \mathrm{Ldlr} r^{--}$, and wild-type mice ( $n=6$ per group) with a high-sucrose diet (including 60\% sucrose and 20\% casein). After 6 weeks on the diet, plasma levels of cholesterol in $\mathrm{Arb}^{-1-}$ mice $(301 \pm 34 \mathrm{mg} / \mathrm{dl})$ were 3 -fold higher than those of wild-type mice $(103 \pm 9 \mathrm{mg} / \mathrm{dl})$ but much lower than those of $\mathrm{Ldlr}^{-/}$mice $(1148 \pm 214 \mathrm{mg} / \mathrm{dl}$; Table 1 and Figure 1A). The plasma levels of triglyceride were also higher in $\mathrm{Ldll}^{\prime /}$ - mice $(208 \pm 14 \mathrm{mg} / \mathrm{dl})$ than in $\mathrm{Arb}^{-/}$mice $(101 \pm 12 \mathrm{mg} / \mathrm{dl})$ or wild-type animals $(75 \pm 7 \mathrm{mg} / \mathrm{dl})$. The plasma cholesterol and triglyceride levels in $A r b^{+/-}$mice and wild-type mice were not significantly different after sucrose feeding. Thus, a single functional ARH allele was sufficient to handle the increase in VLDL production associated with a high-sucrose diet.

Next we fractionated the lipoproteins to determine the distribution of cholesterol among the different lipoprotein particles. The cholesterol content of VLDL and LDL was dramatically increased in sucrose-fed $L d l r^{-/}$mice, with a greater accumulation in the VLDL fractions (Figure 1B). The increase in cholesterol content of the VLDL and LDL fractions was much more modest in the $\mathrm{Arb}^{-/-}$mice than in the $\mathrm{Ldlr}^{-/}$animals and occurred primarily in particles in the LDL size range.

VLDL synthesis is similar in Arb-/, $\mathrm{Ldlr}^{-1}$, and wild-type mice. The more modest increase in apoB-containing lipoprotein levels in the sucrose-fed $\mathrm{Arb}^{-/-}$mice could be due to lower rates of VLDL production in these animals. To test this hypothesis, we injected both the chow-fed and sucrose-fed mice with the lipase inhibitor

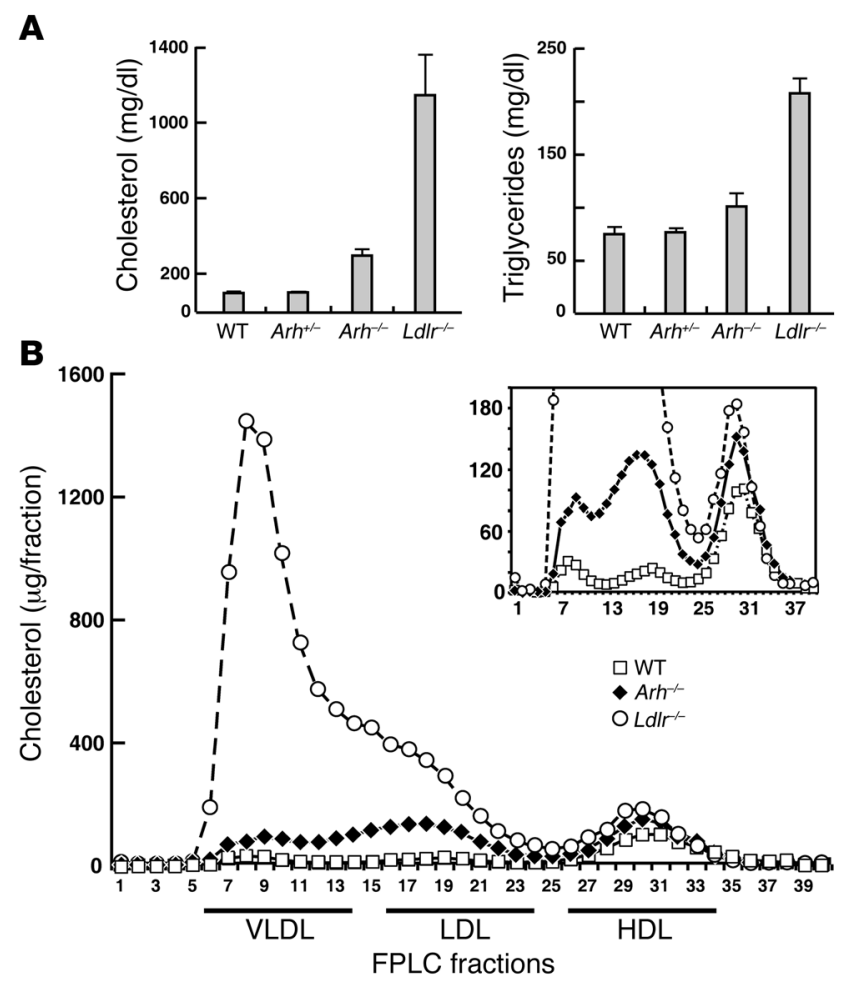


A

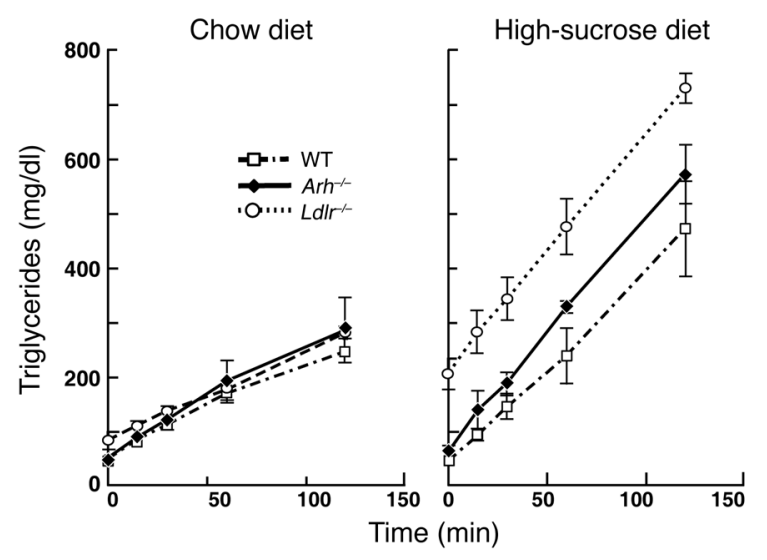

B

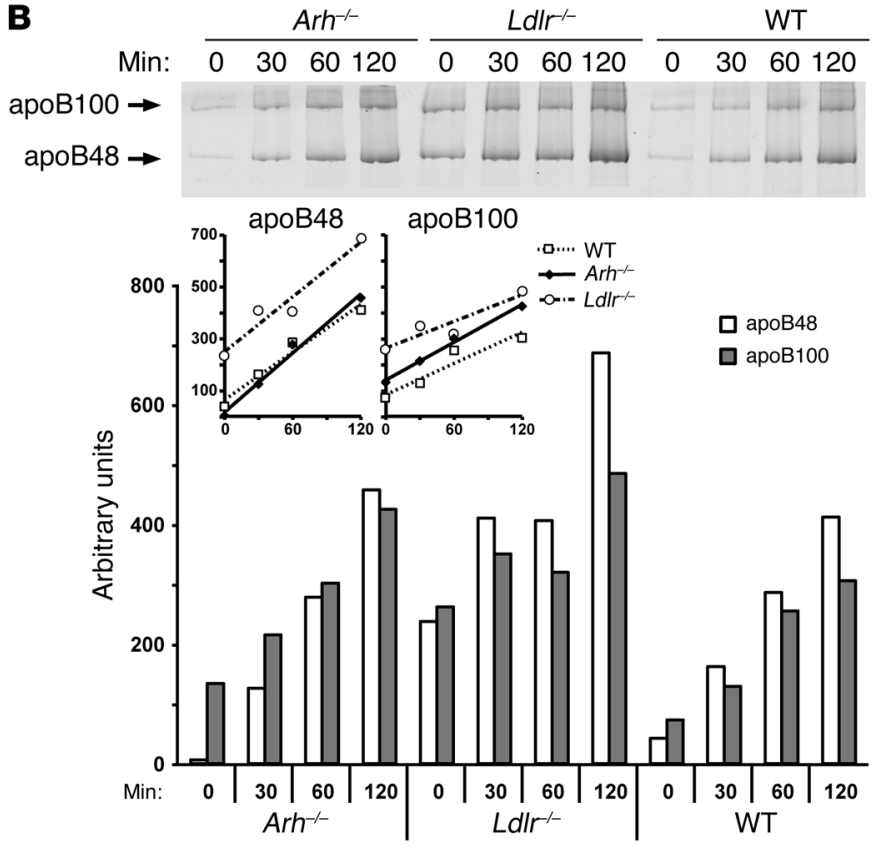

Figure 2

VLDL production rates of $A r h^{--}$, Ldlr $r^{--}$, and wild-type mice on normal chow and high-sucrose diets. (A) Male Arh ${ }^{-1-}$ (diamonds), Ldlr ${ }^{-1-}$ (circles), and wild-type (squares) mice (14-16 weeks of age) were injected with $300 \mathrm{mg} / \mathrm{kg}$ Triton WR-1339 (15\% w/v in $0.9 \%$ NaCl). Prior to injection, the mice were maintained on a normal chow diet (left) or a high-sucrose diet (right) for 6 weeks. Blood was sampled from the retro-orbital plexus after a 6-hour fast at the time points indicated, and the triglycerides were measured enzymatically as described in Methods. VLDL production rates were calculated from the slope of a line determined using least squares regression. (B) apoB production in $\mathrm{Arh}^{-1-}$, $\mathrm{Ldll}^{-1-}$, and wild-type mice. Male Arh ${ }^{-/-}$(diamonds), Ldlr ${ }^{-1}$ (circles), and wild-type (squares) mice $(n=4), 18-22$ weeks of age, on a chow diet were injected with $300 \mathrm{mg} / \mathrm{kg}$ Triton WR-1339 (15\% w/v in $0.9 \% \mathrm{NaCl}$ ) after a 6 -hour fast. Blood was sampled from the retro-orbital plexus at the times indicated. Plasma aliquots from individual mice were pooled, and VLDL was separated as described in Methods. The resulting apolipoproteins were separated by SDS-PAGE and stained with colloidal Coomassie blue. Scanning densitometry was used to determine the relative amounts of apoB48 and apoB100 in each sample.

Triton WR-1339 and monitored changes in plasma triglyceride and apoB levels. The rates of appearance of triglyceride in the plasma were not significantly different $(P>0.38)$ in the chow-fed $A r b^{-/-}(1.9 \pm 0.7 \mathrm{mg} / \mathrm{dl} / \mathrm{min}), L d l r^{-/}(1.7 \pm 0.1 \mathrm{mg} / \mathrm{dl} / \mathrm{min})$, and wild-type mice $(1.6 \pm 0.1 \mathrm{mg} / \mathrm{dl} / \mathrm{min})$ (Figure $2 \mathrm{~A})$. On the highsucrose diet, the plasma triglyceride levels differed at baseline and throughout the experiment among the 3 strains, but the rates of increase in triglyceride levels after Triton injection were similar in $A r b^{-/-}(4.2 \pm 0.8 \mathrm{mg} / \mathrm{dl} / \mathrm{min}), L_{d l r^{--}}(4.3 \pm 0.7 \mathrm{mg} / \mathrm{dl} / \mathrm{min})$, and wild-type animals $(3.6 \pm 1.25 \mathrm{mg} / \mathrm{dl} / \mathrm{min} ; P>0.5)$ (Figure $2 \mathrm{~A})$. The relative rates of secretion of apoB determined by Coomassie blue staining (Figure 2B) or immunoblotting (data not shown) paralleled those of triglyceride secretion: baseline levels of apoB were markedly higher in $\mathrm{Ldlr}^{-/}$mice, but no differences in the rates of apoB secretion were evident among the 3 strains. These data do not support the notion that the differences in plasma lipid levels of $\mathrm{Arb}^{-1-}$ and $\mathrm{Ldlr} \mathrm{r}^{--}$mice are due primarily to differences in VLDL synthesis and secretion by the liver.

LDLR-dependent clearance of VLDL remnants is partially preserved in $A r b^{-1-}$ mice. The LDLR plays a major role in the removal of VLDL remnants as well as LDL from the plasma (1). To determine whether lower cholesterol levels in the Arb ${ }^{-1-}$ mice are due to preservation of LDLR-mediated VLDL remnant clearance, we measured the rates of clearance of ${ }^{125} \mathrm{I}$-labeled mouse VLDL and rabbit $\beta$-migrating VLDL ( $\beta$-VLDL) from the plasma of $\mathrm{rrb}^{-/-}, \mathrm{Ldl} \mathrm{r}^{--}$, and wild-type mice (8). The half-life of ${ }^{125}$ I-labeled mouse VLDL was not significantly different in $A r b^{-/-}(70 \pm 23$ minutes) and wild-type (64 \pm 9 minutes) animals but was longer in $\mathrm{Ldlr}^{/-}$mice $(362 \pm 60$ minutes, $P<0.01$ ) (Figure $3 \mathrm{~A})$. The clearance of rabbit $\beta$-VLDL was indistinguishable from that of mouse VLDL in these animals (Figure 3A). These data indicate that LDLR-dependent clearance of VLDL remnants is preserved in $\mathrm{Arb}^{-/-}$mice.

Since human LDL binds the mouse LDLR with lower affinity than mouse LDL (21), we generated a strain of mice expressing the human LDLR but no ARH by crossing $\mathrm{Arb}^{-/-}$mice with mice in which a human LDLR minigene was inserted into the mouse $L d l r$ locus ( $b$ LDLR knockin mice) (22). Since the bLDLR is expressed at a 1.3-fold higher level than the wild-type receptor in these animals, we used mice heterozygous for the bLDLR minigene for these studies. The pattern of clearance of human LDL in mice expressing the bLDLR minigene (Figure 3B) was similar to that observed previously in wild-type mice using mouse LDL (20). The clearance of rabbit $\beta$-VLDL was comparable in mice expressing the $b$ LDLR minigene and in wild-type animals (Figure 3B) and replicated the results obtained with mouse VLDL: The halflife of rabbit $\beta$-VLDL was significantly slower $(P<0.025)$ in mice lacking LDLR (127 \pm 30 minutes) but not in those lacking ARH (75 \pm 16 minutes) compared with mice heterozygous for the hLDLR minigene ( $61 \pm 11$ minutes).

Hepatocytes from Arh ${ }^{-/-}$mice internalize $V L D L$ but not $L D L$. To determine whether circulating VLDL were taken up by hepatocytes in $A r b^{-1-}$ mice, we examined and compared the uptake of colloidal 

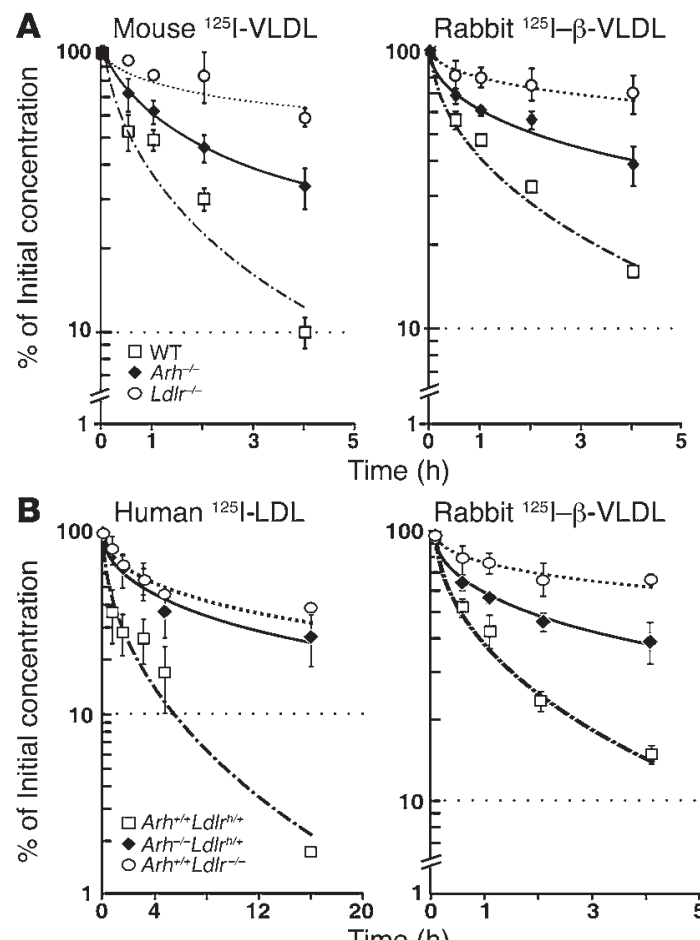

Rabbit ${ }^{125} \mid-\beta$-VLDL

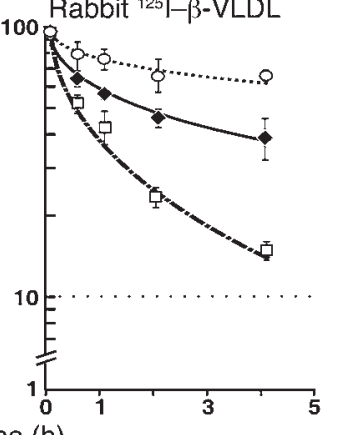

gold-labeled $h$ LDL and $\beta$-VLDL in the livers of $L d l r^{b / h}, L d l r^{b / h} \mathrm{Arb}^{-/-}$, and wild-type mice. The mice used in these experiments were homozygous for the human LDLR allele at the Ldlr locus, since $b$ LDL was used in these experiments. Gold-labeled LDL particles were present in intracellular vesicles (presumed to be endosomes) in the livers of wild-type mice but not in $\mathrm{Arb}^{-1-}$ mice (Figure 4A). Gold-labeled LDL was detected in the sinusoids but not intracellularly in the $L d l r^{b / h} \mathrm{Arb}^{-1-}$ animals (Figure 4A). In contrast with these results, gold-labeled $\beta$-VLDL was abundant within intracellular vesicles in the hepatocytes of the wild-type mice and in mice lacking ARH. Hepatocytes from mice lacking LDLRs did not internalize LDL (not shown) or $\beta$-VLDL (Figure 4B), demonstrating that uptake of VLDL remnants required expression of the LDLR.

To determine whether the differences in the uptake of VLDL remnants and LDL into the hepatocytes was cell autonomous, primary hepatocytes were isolated from $A r b^{+/+} L d l r^{b / h}$, $A r b^{-/-} L d l r^{b / h}$, and $A r b^{+/+} L d l r^{-/-}$mice and incubated with fluorescently labeled hLDL and $\beta$-VLDL. Both 3-pyrenemethyl-23, 24-dinor-5-cholen-22oate- 3 beta-yl oleate (PMCA-O) LDL and 1,1'dioctadecyl-3,3,3',3'-tetramethylindocarbocyanine perchlorate (DiI) $\beta$-VLDL were efficiently taken up by $A r b^{+/+} L d l r^{b / b}$ hepatocytes (Figure 5). Hepatocytes from the $A r b^{-/-} L d l r^{b / h}$ animals failed to internalize any PMCA-O LDL but took up significant amounts of DiI $\beta$-VLDL (Figure 5). As expected, hepatocytes lacking LDLRs failed to internalize either ligand. These results indicate that LDLR-dependent uptake of VLDL remnants is preserved in hepatocytes from $\mathrm{Arb}^{-/-}$animals.

\section{Figure 3}

Clearance of circulating VLDL but not LDL is partially preserved in $\mathrm{Arh}^{-1-}$ mice. (A) Clearance of mouse 125 |-VLDL and rabbit ${ }^{125} \mid-\beta$-VLDL in $\mathrm{Arh}^{-/-}, \mathrm{Ldll}^{-1-}$, and wild-type mice. Four wild-type (squares), $\mathrm{Arh}^{-/-}$ (diamonds), and Ldlr ${ }^{-1}$ (circles) 12- to 14-week-old female mice were injected with mouse ${ }^{125 /-V L D L ~(125 ~} \mathrm{cpm} / \mathrm{ng}$ protein) (left) or rabbit ${ }^{125}$ I- $\beta$-VLDL (288 cpm/ng protein) (right). Blood samples were collected by retro-orbital puncture at the indicated times, and the plasma content of isopropanol-precipitable ${ }^{125}$ /-radioactivity was measured. Radioactivity remaining in the plasma was plotted as a percentage of the activity present 2 minutes after injection of the labeled ligand. Before the experiment, the mice were fasted for 6 hours and anesthetized with sodium pentobarbital ( $80 \mathrm{mg} / \mathrm{kg}$ intraperitoneal). (B) Female $\mathrm{Arh}^{+/+} \mathrm{Ldllr}^{h /+}$ (squares), Arh ${ }^{-/-}$Ldll $^{h /+}$ (diamonds), and Ldlr ${ }^{-/-}$(circles) mice ( $n=4$ per genotype), aged 12-14 weeks, were fasted for 4 hours, anesthetized with sodium pentobarbital ( $80 \mathrm{mg} / \mathrm{kg}$ of intraperitoneal), and injected with $15 \mu \mathrm{g}$ 125/-human LDL (125 cpm/ng protein) (left) or $15 \mu \mathrm{g}{ }^{125}$-rabbit $\beta$-VLDL (189 cpm/ng protein) (right). Blood samples were collected and processed as described above.

High-affinity binding is not sufficient for ligand uptake by LDLRsin Arh-/hepatocytes. $\beta$-VLDL binds the LDLR with greater affinity than does LDL (23). To determine whether greater affinity for the receptor is sufficient for internalization of ligand by the LDLR in the absence of ARH, we incubated primary hepatocytes with IgG-C7, a monoclonal antibody with high affinity for the LDLR (24), for 1 hour at $4^{\circ} \mathrm{C}$ and then for 2 hours at $37^{\circ} \mathrm{C}$. After the $4^{\circ} \mathrm{C}$ incubation, LDLR was detected exclusively on the surface of both $A r b^{-/-} L d l r^{b / h}$ and $A r b^{+/+} L d l r^{b / b}$ hepatocytes (Figure 6A). After warming the cells to $37^{\circ} \mathrm{C}$, the IgG-C7 was redistributed from the cell surface to perinuclear vacuoles in the $A r b^{+/+} L d l r^{b / h}$ hepatocytes. In contrast, almost all the IgG-C7 remained associated with the cell surface in the $A r b^{-/-} L d l r^{b / b}$ hepatocytes. No specific staining was detected in the $A r b^{+/+} \mathrm{Ldlr}^{-/}$cells or when using an irrelevant antibody, IgG-2001 (data not shown). Thus, despite binding with
A
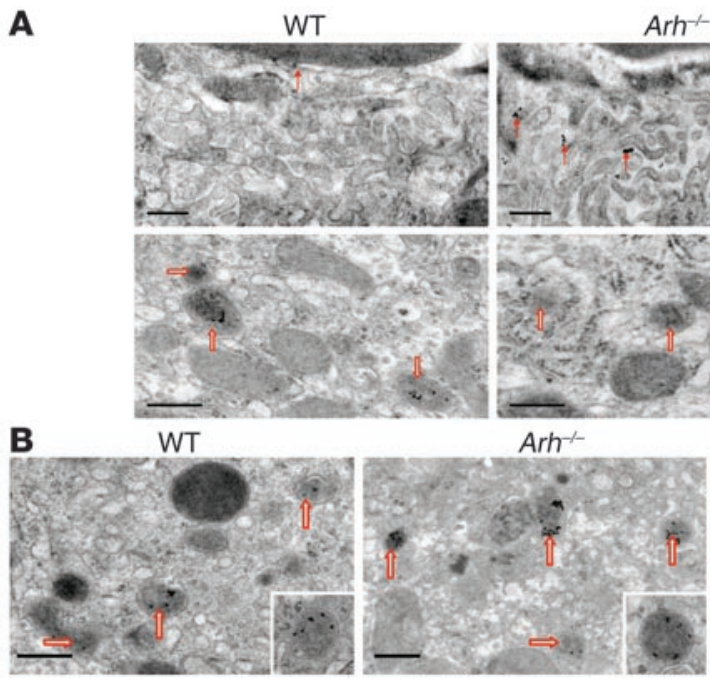

$\mathrm{Arh}^{--}$
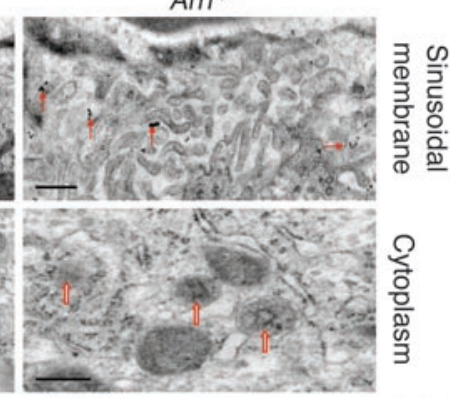

\section{음
$\frac{0}{0}$
$\frac{0}{3}$}

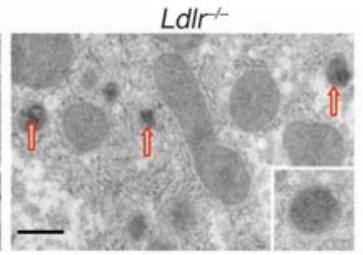

\section{Figure 4}

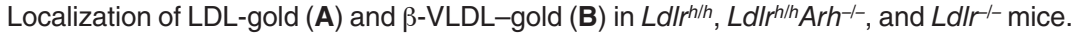
Mice were injected via the tail vein with $50 \mu \mathrm{g}$ of colloidal gold-labeled human LDL or rabbit $\beta$-VLDL. After 2 hours, mice were sacrificed. Livers were perfused, fixed, and then processed for electron microscopy as described in Methods. Solid arrows indicate gold particles associated with villi on the sinusoidal membrane, and open arrows indicate endosomes. Scale bars: $0.5 \mu \mathrm{m}$. 

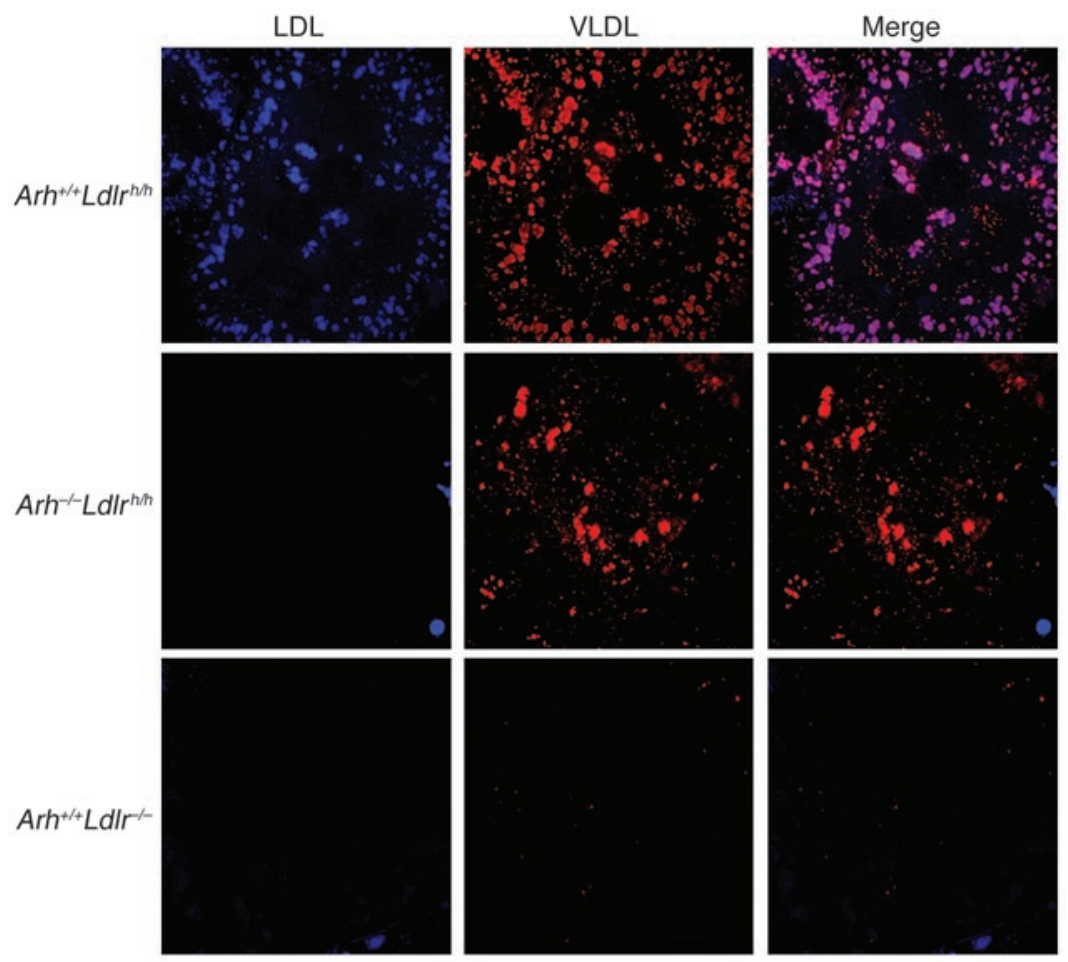

\section{Figure 5}

PMCA-O LDL and Dil $\beta$-VLDL uptake by primary

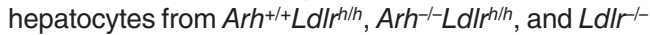
mice. On day 0 , primary hepatocytes were isolated

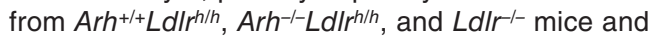
incubated overnight in DMEM containing $5 \%$ lipoprotein-deficient serum. The next morning, the cells were incubated at $37^{\circ} \mathrm{C}$ in fresh media containing $25 \mu \mathrm{g}$ PMCA-O LDL and $25 \mu \mathrm{g}$ Dil $\beta$-VLDL for 5 hours. The cells were washed, fixed, and mounted as described in Methods. Images were procured by deconvolution microscopy. Original magnification, $\times 84$. high affinity to the LDLR, IgG-C7 failed to be internalized in a fashion similar to that of $\beta$-VLDL in $\mathrm{Arb}^{-/-}$cells.

In addition to having a higher affinity for the LDLR, $\beta$-VLDL also contains multiple copies of apoE, each of which is capable of binding the receptor. Thus, a single $\beta$-VLDL particle may simultaneously bind multiple LDLRs (25). In contrast, LDL has only a single copy of apoB100 and binds the LDLR with a one-to-one stoichiometry. To determine whether multivalency of the ligand is sufficient for LDLR internalization in the absence of ARH, we created a multivalent ligand by incubating the monoclonal antibody IgG-C7 with protein A. Protein A has 4 high-affinity IgG-binding sites and should form a tetrameric ligand for the LDLR when incubated with IgG-C7. The protein A:IgG-C7 tetramers were incubated with primary hepatocytes at $4{ }^{\circ} \mathrm{C}$ for 1 hour. At $4^{\circ} \mathrm{C}$, the tetramers were only detected at the cell surface in the $A r b^{+/+} L d l r^{b / h}$ and $A r b^{-/-} L d l r^{b / b}$ hepatocytes. The cells were then warmed to $37^{\circ} \mathrm{C}$ for 2 hours. After warming to $37^{\circ} \mathrm{C}$, protein A:IgG-C7 was no longer observed on the cell surface of $A r b^{+/+} L d l r^{b / b}$ hepatocytes and was apparent in punctate vesicles within the cell (Figure 6B). In contrast, the IgG-C7 tetramers remained at the cell surface of the $A r b^{-1-} L d l r^{b / b}$ hepatocytes after warming to $37^{\circ} \mathrm{C}$. No specific staining was observed in the $A r b^{+/+} L d l r^{-/-}$hepatocytes (Figure 6B) or when an irrelevant antibody:protein A complex was used.

LDLR-related protein is not required for $\beta-V L D L$ uptake by Arb -1- $^{-1}$ hepatocytes. It is also possible that the LDLR binds VLDL and then transfers it to (or forms a complex with) a second receptor on the cell surface, such as the LDLR-related protein (LRP), for internalization. In this model, an alternative adaptor that recognizes the cytoplasmic tail of LRP could mediate internalization of the complex, obviating the requirement for ARH. To test this hypothesis, we examined the effects of LRP deletion on $\beta$-VLDL uptake in ARH-deficient animals. Mice lacking ARH were crossed with mice containing loxP sites at the LRP locus

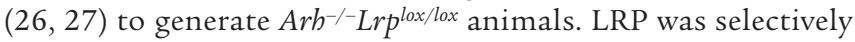
deleted in the livers of these animals by introduction of a transgene expressing Cre recombinase $\left(A r b^{-/-} L r p^{l o x / l o x} \mathrm{Cre}^{+}\right)$under the control of the albumin promoter (28). Deletion of LRP markedly impaired clearance of $\alpha 2$-macroglobulin, an established ligand for LRP, but did not affect clearance of VLDL remnants in Arb-/animals. Primary hepatocytes from $\mathrm{Arb}^{-/-} \mathrm{Lrp}^{l o x} / \mathrm{lox} C r \mathrm{C}^{-}$mice internalized both $\beta$-VLDL and $\alpha 2$-macroglobulin (Figure 7 ). Deletion of LRP in these cells did not reduce the uptake of $\beta$ VLDL despite abolishing the internalization of $\alpha 2$-macroglobulin. These findings indicate that the LDLR-dependent internalization of $\beta$-VLDL in $\mathrm{Arh}^{-/-}$hepatocytes does not require LRP.

\section{Discussion}

In this study, we showed that VLDL but not LDL is rapidly removed from the circulation and internalized by hepatocytes of $\mathrm{Arh}^{-/-}$mice. Previously, we showed that ARH is required for LDLR-mediated clearance of LDL; the FCR of LDL in mice lacking $\mathrm{ARH}\left(\mathrm{Arb}^{-/-}\right.$mice $)$is equivalent to that of mice lacking LDLRs ( $L d l r^{-/}$mice) (20). Here we show that the clearance of circulating VLDL remnants is largely preserved in mice lacking ARH. As a result, $\mathrm{Arb}^{-1-}$ mice have near normal plasma levels of cholesterol on chow diets and are significantly protected from the hypercholesterolemic effects of a sucrose-rich diet. These data indicate that the requirements for hepatic LDLR function are ligand specific. $\mathrm{ARH}$ is required for internalization of the LDLR in the absence of ligand or in the presence of monovalent ligands such as LDL or the monoclonal antibody $\mathrm{C} 7$ but not for internalization of VLDL remnants. The preservation of VLDL remnant clearance by ARH-deficient hepatocytes likely contributes to the reduced clinical severity observed in individuals with ARH compared with patients with no LDLR function (1-4, 13-18). 
A
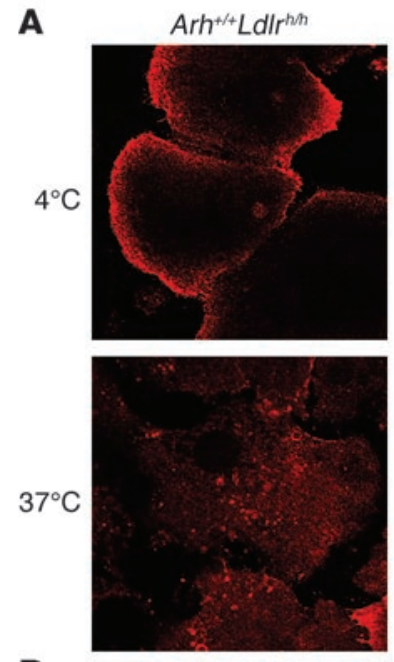

B
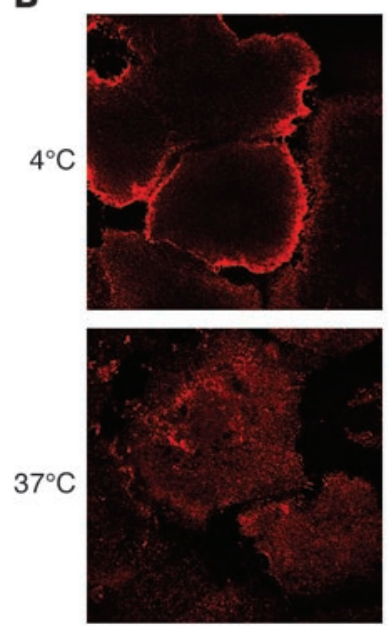

Figure 6

Internalization of IgG-C7 and IgG-C7:protein A complexes in primary hepatocytes.

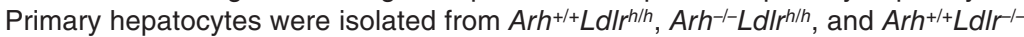
mice and incubated for 1 hour at $4^{\circ} \mathrm{C}$ with either (A) IgG-C7 or (B) IgG-C7 complexed with protein A. Cells were then warmed to $37^{\circ} \mathrm{C}$ for 2 hours. IgG-C7 was detected by indirect immunofluorescence confocal microscopy. Original magnification, $\times 130$.

The phenotype of mice fed a high-sucrose diet resembles that of mice expressing high levels of the sterol regulatory element binding protein-1a (SREBP-1a) (29). Overexpression of SREBP-1a in the liver leads to increased expression of enzymes in the fatty acid biosynthetic pathway, massively increasing the biosynthesis of fatty acids, resulting in severe hepatic steatosis. Despite marked increases in VLDL secretion, overexpression of SREBP-1a does not increase circulating lipoprotein levels except when the LDLR is inactivated. Mice that overexpress SREBP-1a and lack functional LDLR are extremely hyperlipidemic (29). In similar fashion, mice fed high-sucrose diets do not become hyperlipidemic despite substantially increased secretion of VLDL into the circulation, as long as LDLR function is intact (29). Thus, the relative resistance of $\mathrm{Arb}^{-1-}$ mice to the hypercholesterolemic effects of the high-sucrose diet indicates that LDLR-dependent clearance of VLDL is preserved in these animals. Comparison of the plasma lipoprotein profiles of sucrose-fed $\mathrm{Arb}^{-/-}$and sucrose-fed $\mathrm{Ldlr}^{-/-}$mice also reveals an important qualitative difference: the mice lacking LDLRs accumulate primarily VLDLsized particles whereas most of the particles that accumulate in the $\mathrm{Arb}^{-/-}$mice are LDL (Figure 1). Taken together, these results indicate that the LDLR internalizes both VLDL and LDL and that LDLR-dependent uptake of VLDL but not LDL is preserved in $\mathrm{Arb}^{-/-}$mice.

Electron microscopy of colloidal gold-labeled lipoproteins revealed that circulating VLDL remnants are internalized by hepatocytes in the $\mathrm{Arb}^{-/-}$ mice whereas LDL is not. The ability of hepatocytes to internalize $\beta$-VLDL but not LDL was recapitulated in vitro in primary hepatocytes isolated from $A r b^{-/-}$animals. These findings contrast with a prior report that $\mathrm{Arh}^{-1-}$ hepatocytes grown ex vivo are competent to internalize LDL (30). It is possible that the difference in results in the 2 sets of experiments reflects differences in the time intervals between the procurement of the cells and the performance of the study. Our uptake studies were performed after the cells were maintained in culture for less than 18 hours whereas the prior study used a longer interval (>48 hours). Alternatively, the differences may reflect differences in LDL preparation. In the present study, we removed all LDL aggregates prior to addition of LDL to the cultured cells.

The mechanistic basis for the differences in LDLRmediated uptake of LDL and $\beta$-VLDL in $\mathrm{Arb}^{-/-}$mice is not known. VLDL remnants contain multiple copies of apoE and bind with higher affinity to the LDLR than do LDLs, which bind the receptor via a single copy of apoB (23). Previously, Michaely et al. demonstrated that the LDLRs on the surface of $A r b^{-1-}$ lymphocytes have a reduced capacity to bind LDL relative to either VLDL or IgG-C7, suggesting that ARH may act as a competency factor for LDL binding (31). Arb ${ }^{-/-} L d l r^{b / h}$ hepatocytes bound but did not internalize IgG-C7, suggesting that highaffinity binding is not sufficient for internalization of ligand in $\mathrm{Arb}^{-/-}$cells. Thus, the differences in LDLR-mediated internalization of LDL and $\beta$-VLDL in $\mathrm{Arb}^{-/-}$cells appear not to be due to differences in affinity of the receptor for the ligand. An alternative possibility is that the multiple apoE peptides on each VLDL remnant may facilitate clustering of the LDLRs and bypass the requirement of $\mathrm{ARH}$ in internalization of the ligand-receptor complex. It is not known if clustering of LDLR is sufficient for internalization of the receptor, but clustering of APOER 2 or VLDLR, 2 closely related LDLR family members, has been shown to be sufficient for signaling through the PTB domain-containing adaptor protein Dab1 (32). To construct a surrogate multivalent ligand for VLDL remnant, we used protein A to assemble tetramers of the monoclonal anti-LDLR antibody IgG-C7. IgG-C7 tetramers bound efficiently to the surfaces of $A r b^{-/-} L d l r^{b / h}$ hepatocytes, but the complexes failed to be internalized at $37^{\circ} \mathrm{C}$. Similarly, aggregation of LDL by vortexing did not result in uptake by ARH-deficient cells (data not shown). These findings do not support the notion that VLDL-mediated clustering of LDLRs obviates the need for ARH but also do not completely rule out this possibility. The multiple apoE moieties on VLDL remnants may adopt a conformation 
A

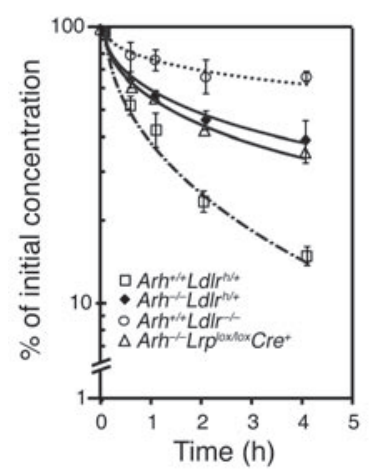

B
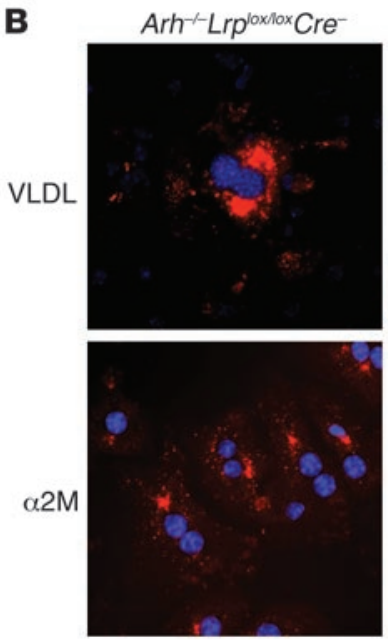

$\mathrm{Arh}^{-1-} \mathrm{Lrp}^{\text {loxilox }} \mathrm{Cre}^{+}$
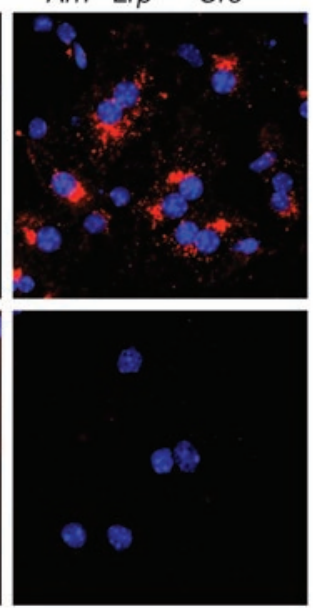

\section{Figure 7}

Deletion of LRP does not reduce $\beta$-VLDL clearance in Arh ${ }^{-/-}$mice. (A) Mice $(n=3$ per group) were fasted for 4 hours, anesthetized with sodium pentobarbital, and injected with 125I-labeled rabbit $\beta$-VLDL $(15 \mu \mathrm{g})$ via the external jugular vein. Venous blood was collected from the retro-orbital plexus at the indicated times, and the plasma content of isopropanolprecipitable ${ }^{125}$-radioactivity was measured. Radioactivity remaining in the plasma was plotted as a percentage of the activity present 2 minutes after injection of the labeled ligand. The experiment was repeated, and similar results were obtained. (B) Primary hepatocytes were isolated from $\mathrm{Arh}^{-1-} \mathrm{Lrp}^{10 \times / l o x} \mathrm{Cre}^{-}$and $\mathrm{Arh}^{-1-} \mathrm{Lrp}^{10 x / l o x} \mathrm{Cre}^{+}$mice and incubated overnight in DMEM containing $5 \%$ lipoprotein-deficient serum. The next morning, the cells were incubated with $15 \mu \mathrm{g} / \mathrm{ml}$ Dil $\beta$-VLDL or $10 \mu \mathrm{g} / \mathrm{ml}$ methylamine-activated $\alpha 2$-macroglobulin ( $\alpha 2 \mathrm{M}$ ) (51) for 30 minutes. The cells were washed, fixed, and mounted as described in Methods. Images were taken by deconvolution microscopy. Original magnification, $\times 84$.

required for LDLR endocytosis that our antibody complexes or aggregated LDL did not replicate.

A third possibility is that VLDL remnants bind LDLRs that decorate the surface of $\mathrm{Arb}^{-/-}$hepatocytes but that internalization is mediated by another cell surface component, such as LRP or heparan sulfate proteoglycans. Genetic deletion of LRP, which abolished the uptake of the $\alpha 2$-macroglobulin, did not reduce the uptake of $\beta$-VLDL by $A r b^{-/-}$cells. Similarly, treatment of primary hepatocytes with heparinase did not affect $\beta$-VLDL uptake (Supplemental Figure 2). These data suggest that LRP and heparan sulfate proteoglycans are not required for LDLRdependent uptake of VLDL remnants in the absence of ARH. Nonetheless, we cannot exclude the possibility that another, as yet unidentified cell surface component, mediates ARH-independent internalization of $\beta$-VLDL.

Prior studies also reported differences in the cellular uptake and metabolism of $\beta$-VLDL when compared with $\operatorname{LDL}(33,34)$. Tabas et al. (33) reported that LDL and $\beta$-VLDL are delivered to different intracellular vesicles in mouse peritoneal macrophages; $\beta$-VLDL stimulated the activity of acyl-CoA/cholesterol acyltransferase activity whereas LDL did not. The difference in cellular trafficking of the 2 lipoproteins was apparent early in their intracellular itinerary (33) and appeared to reflect differences in the endocytic mechanisms by which the lipoproteins were internalized (34). It is not known whether ARH contributes to differences in the uptake of LDL and $\beta$-VLDL in macrophages. Nonetheless, these studies raise the possibility that lipoproteins internalized by $\mathrm{ARH}$-dependent and ARH-independent routes may have different intracellular itineraries and metabolic effects.

Twisk et al. have shown that inactivation of the LDLR results in an increase in apoB secretion by cultured hepatocytes (35). We failed to find evidence for an increase in VLDL secretion rates in either the $A r b^{-/-}$mice or the $\mathrm{Ldlr}^{-/-}$mice when we measured apoB secretion in vivo. These results are consistent with other in vivo studies in mice that have failed to report an increase in apoB secretion in the absence of the $\operatorname{LDLR}(36,37)$. Multiple factors may contribute to the differences in the results obtained when VLDL secretion is analyzed in cell culture and in vivo. Although we cannot rule out the possibility that subtle differences in VLDL synthesis among the $\mathrm{Arb}^{-/-}, \mathrm{Ldlr}^{-/}$, and wild-type mice exist, they appear to play a more modest role than the differences in VLDL clearance in accounting for the lower plasma levels of cholesterol in the $\mathrm{Arb}^{-/-}$mice compared with the $\mathrm{Ldlr}^{/-}$mice.

The results of this study provide insights into 2 paradoxical observations in ARH patients. LDL turnover studies have shown that the defect in clearance of circulating LDL in ARH patients is comparable to that of patients with homozygous $\mathrm{FH}$, yet $\mathrm{ARH}$ patients have lower LDL-C levels and develop symptomatic coronary heart disease significantly later in life. In $\mathrm{FH}$, the rate of clearance of LDL precursor particles is decreased; therefore, the severe hypercholesterolemia associated with this condition results from an increase in LDL production as well as a decrease in LDL clearance (1). If the clearance of VLDL remnants is preserved in ARH individuals as it is in Arb-/mice, then LDL production rates would not be increased in these patients. Increasing LDLR expression should further enhance the removal of LDL precursors even in the absence of $A R H$, resulting in lower levels of LDL-C. The increased clearance of VLDL remnants due to increased $L D L R$ expression may explain the greater LDL-lowering effect of HMG-CoA reductase inhibitors in ARH compared with homozygous FH $(1,13-16,18)$.

\section{Methods}

General methods. Cholesterol and triglyceride levels in the liver and plasma were measured enzymatically as described previously (38). Plasma lipoprotein fractions were separated by fast-performance liquid chromatography (FPLC) using a Superose 6 column (Amersham Biosciences), and the cholesterol content of the fractions was determined as described $(29,39)$. Protein concentrations were determined using the Lowry method (40). The anti-LDLR monoclonal antibody IgG-C7, which recognizes the second ligand-binding domain of the LDLR, was generated as described previously (24).

Lipoproteins. Human LDL $(d=1.019-1.063 \mathrm{~g} / \mathrm{ml})$ was prepared by sequential ultracentrifugation (41). $\beta$-VLDL $(d<1.006)$ was isolated from the plasma of cholesterol-fed rabbits as described (42). Mouse VLDL was prepared from the plasma of $30 \mathrm{Ldll}^{-/}$mice fed a diet containing $1.25 \%$ cholesterol, $7.5 \%$ cocoa butter, $7.5 \%$ casein, and $0.5 \%$ cholic acid, and the mouse LDL was prepared from $80 \mathrm{Ldll}^{-/}$- mice fed a chow diet exactly as described (43). The LDL and $\beta$-VLDL were radiolabeled using the BoltonHunter reagent (44), purchased from Amersham Biosciences. Fluorescent 
LDL (PMCA-O LDL) was synthesized by reconstituting the lipid core of LDL with PMCA-O as described (45), with minor modifications. After reconstitution with PMCA-O, fluorescently labeled LDL monomers were separated from aggregated LDL via FPLC using a Superose 6 column. $\beta$-VLDL was fluorescently labeled with DiI as described (46). Colloidal goldlabeled LDL and $\beta$-VLDL were produced as previously described $(31,47)$.

Mice and diets. All mice used in these studies were maintained on a hybrid genetic background of C57BL/6J and 129Sv strains. All protocols used in the studies described were approved by the Institutional Animal Care and Research Advisory Committee at the University of Texas Southwestern Medical Center. Comparisons were made among littermates. Mice with genetic disruption of Arb or Ldlr have been previously described $(20,48)$. Mice expressing the human LDLR at the endogenous mouse $L d l r$ locus ( $h L D L R$ knockin mice) (22) were crossed with the $A r b^{-/-}$mice to develop mice expressing the human LDLR and no ARH $\left(\mathrm{Ldl}^{b /+} \mathrm{Arb}{ }^{-/-}\right)$. All mice were housed on a 12-hour dark/12-hour light cycle and maintained on standard chow containing $6 \%(\mathrm{w} / \mathrm{w})$ animal fat and $0.02 \%(\mathrm{w} / \mathrm{w})$ cholesterol (Teklad 6\% mouse/rat diet 7002; Harlan Teklad) as well as water ad libitum unless otherwise stated. The Western diet was synthesized by supplementing normal chow with $21 \%(\mathrm{w} / \mathrm{w})$ anhydrous milk fat and $0.2 \%$ cholesterol. The high-sucrose diet (no. 960237; MP Biomedicals) contained $60.2 \%$ sucrose, $20 \%$ casein, $15 \%$ cellulose, $0.3 \%$ DL-methionine, $3.5 \%$ minerals and vitamins, and less than $0.2 \%$ fat.

Measurement of VLDL production. Mice were fasted for 6 hours at the beginning of the light cycle. The mice were anesthetized with sodium pentobarbital $(80 \mathrm{mg} / \mathrm{kg})$ and then injected in the external jugular vein with a bolus of $300 \mathrm{mg} / \mathrm{kg}$ Triton WR-1339 (Tyloxapol; Sigma-Aldrich) in $0.9 \% \mathrm{NaCl}$ (15\% Triton WR-1339; w/v). Blood samples were collected in EDTA-coated tubes (Microvette $500 \mathrm{KE}$; Sarstedt) from the retro-orbital plexus at the indicated time points. Aliquots of plasma from individual mice were measured for triglyceride content as described above. The remaining plasma was pooled, and VLDL was separated by ultracentrifugation over $0.9 \% \mathrm{NaCl}$ at $436,000 \mathrm{~g}$ for 45 minutes. The VLDL fraction was removed and precipitated with trichloroacetic acid. The pellet was washed in ice-cold acetone and resuspended in SDS sample buffer. Component apoproteins were then separated by $5 \%$ SDS PAGE. The gels were stained overnight in colloidal Coomassie blue (Invitrogen). Relative quantities of apo 48 and apoB100 were determined by densitometry using ImageQuant 5.0 (Molecular Dynamics). Staining between gels was normalized using a standard curve of human apoB100 included on each gel. The secretion rates of triglycerides were calculated by linear regression of plasma triglyceride concentrations against time.

Clearance of $L D L$ and VLDL from plasma. Lipoproteins were radiolabeled with ${ }^{125}$ iodine, and clearance rates of LDL and VLDL were determined as previously described $(48,49)$. In brief, mice were anesthetized with sodium pentobarbital $(80 \mathrm{mg} / \mathrm{kg})$ and injected via the external jugular vein with a $0.2 \mathrm{ml}$ bolus of either ${ }^{125} \mathrm{I}$-LDL $(15 \mu \mathrm{g})$ or ${ }^{125} \mathrm{I}$-VLDL $(15 \mu \mathrm{g})$ in $10 \mathrm{mM}$ TrisCl, pH 7.4, $150 \mathrm{mM} \mathrm{NaCl}$, and $0.2 \%(\mathrm{w} / \mathrm{v})$ BSA. Venous blood was collected from the retro-orbital plexus in EDTA-coated tubes at the indicated times (Microvette $500 \mathrm{KE}$; Sarstedt). The plasma content of ${ }^{125}$ I-labeled apoB was measured by $\gamma$ counting after isopropanol precipitation. The half-lives of VLDL and LDL were calculated from the decay curve of the lipoproteins. The amount of ${ }^{125} \mathrm{I}-\mathrm{LDL}$ or ${ }^{125} \mathrm{I}-\mathrm{VLDL}$ remaining in the plasma was expressed as a percentage of the initial concentration, measured as the amount of ${ }^{125}$ I-radioactivity in the plasma 2 minutes after injection. The logarithm of the amount of lipoprotein remaining in the plasma was plotted against time, and the decay curve was fitted using a second-order polynomial equation.

In vivo uptake of colloidal gold-labeled $L D L$ and VLDL. A total of approximately $50 \mu \mathrm{g}$ of colloidal gold-labeled human LDL or rabbit $\beta$-VLDL was injected into the tail veins of male mice. The mice were sacrificed after 2 hours and perfused via cardiac puncture with warm HBSS followed by $4 \%$ paraformaldehyde (PFA) in PBS. The livers were removed, diced, and fixed with $2 \%$ glutaraldehyde and post-fixed in $1 \%(\mathrm{w} / \mathrm{v})$ osmium tetroxide. The specimens were rinsed in distilled water, dehydrated with graded ethanol, and then Epon-embedded according to the manufacture's protocol (Electron Microscopy Sciences). Ultrathin sections ( $~ 80 \mathrm{~nm})$ were cut with a diamond knife using a Leica ULTRACUT R ultramicrotome and placed on Formvar/carbon-coated nickel grids. Sections were stained with $3 \%$ aqueous uranyl acetate (15 minutes) and lead acetate (5 minutes). Electron micrographs were taken using a JEOL 1200 electron microscope operating at $80 \mathrm{kV}$.

Uptake of fluorescent lipoproteins by primary hepatocytes. Primary hepatocytes were isolated from mice of the indicated genotypes as described, with minor modifications (29). Mice were anesthetized and the livers perfused via the portal vein with $30 \mathrm{ml}$ of prewarmed Liver Perfusion Media (17701-038; Invitrogen) followed by $30 \mathrm{ml}$ prewarmed Liver Digest Media (17703-034; Invitrogen) at approximately $3 \mathrm{ml} / \mathrm{min}$. The livers were removed from the animals, and the Glisson capsule was stripped. The dissociated cells were dispersed by shaking, followed by filtration through $100-\mu \mathrm{m}$ nylon filter into an equal volume of cold buffer A (DMEM, $5 \%$ [v/v] fetal calf serum, $100 \mu \mathrm{g} / \mathrm{ml}$ penicillin, $100 \mu \mathrm{g} / \mathrm{ml}$ streptomycin, $10 \mathrm{mM}$ HEPES, $\mathrm{pH}$ 7.4). The cells were washed twice at $4{ }^{\circ} \mathrm{C}$ with buffer $\mathrm{A}$ and counted with a hemacytometer, and $5 \times 10^{5}$ hepatocytes were plated onto collagen I-coated coverslips (354089; BD Biosciences) in DMEM containing 5\% (v/v) lipoprotein-deficient serum, $100 \mu \mathrm{g} / \mathrm{ml}$ penicillin, and $100 \mathrm{mg} / \mathrm{ml}$ streptomycin for 5 hours at $37^{\circ} \mathrm{C}$. The cells were washed with PBS and incubated in DMEM containing $5 \%$ lipoprotein-deficient serum for 12 hours at $37^{\circ} \mathrm{C}$ in $5 \% \mathrm{CO}_{2}$. A total of $25 \mu \mathrm{g} / \mathrm{ml}$ PMCA-O LDL or $25 \mu \mathrm{g} / \mathrm{ml}$ DiI VLDL was added to the medium. After the indicated time period, the hepatocytes were washed at $4{ }^{\circ} \mathrm{C}$ twice for 10 minutes with buffer B $(50 \mathrm{mM}$ Tris$\mathrm{HCl}, \mathrm{pH} 7.4,150 \mathrm{mM} \mathrm{NaCl}, 2 \mathrm{mg} / \mathrm{ml} \mathrm{BSA}$ ) and once briefly with buffer C (50 mM Tris- $\mathrm{HCl}, \mathrm{pH} 7.4,150 \mathrm{mM} \mathrm{NaCl}$ ). Cells were then fixed with $4 \%$ PFA in buffer $\mathrm{D}$ ( $20 \mathrm{mM}$ sodium phosphate, $150 \mathrm{mM} \mathrm{NaCl}, 2 \mathrm{mM} \mathrm{MgCl}_{2}$ ) at $25^{\circ} \mathrm{C}$ for 15 minutes. Cells were then briefly washed with $50 \mathrm{mM} \mathrm{NH}_{4} \mathrm{Cl}$, then washed twice with buffer $\mathrm{C}$ and once with deionized $\mathrm{H}_{2} \mathrm{O}$. Coverslips were mounted on slides with Shandon Immu-Mount (Thermo Electron Corp.). Images were acquired using a DeltaVision RT deconvolution microscope running softWoRx Explorer Suite 1.1 (Applied Precision).

Internalization of monoclonal IgG and IgG:protein A complexes by primary hepatocytes. Primary hepatocytes were isolated as described (see above). Hepatocytes were washed with cold PBS and incubated at $4^{\circ} \mathrm{C}$ for 1 hour with $20 \mu \mathrm{g} / \mathrm{ml} \mathrm{IgG-C7}$ in medium A supplemented with $20 \mathrm{mM}$ HEPES, $\mathrm{pH}$ 7.4. The cells were then warmed to $37^{\circ} \mathrm{C}$ for the times indicated, after which the coverslips were washed twice for 10 minutes with ice-cold buffer $\mathrm{B}$ and once briefly with buffer $\mathrm{C}$. The cells were fixed for 15 minutes at $25^{\circ} \mathrm{C}$ with $4 \% \mathrm{PFA}$ in buffer $\mathrm{D}$, washed once in $50 \mathrm{mM} \mathrm{NH}_{4} \mathrm{Cl}$ and once in buffer $\mathrm{D}$, and then permeabilized for 10 minutes at $-10^{\circ} \mathrm{C}$ with $0.05 \%$ $(\mathrm{v} / \mathrm{v})$ Triton X-100 in buffer D. The cells were incubated for 1 hour at $25^{\circ} \mathrm{C}$ in buffer D supplemented with $10 \%(\mathrm{v} / \mathrm{v})$ goat serum and $20 \mathrm{mg} / \mathrm{ml}$ BSA and then for 2 hours in $20 \mu \mathrm{g} / \mathrm{ml}$ Alexa Fluor 534 goat anti-mouse antibody (Invitrogen) in the same buffer. The cells were washed 3 times with $1 \mathrm{mg} / \mathrm{ml} \mathrm{BSA}$ in buffer D and once briefly in deionized water before mounting. Images were acquired using the Leica TCS SP laser scanning confocal microscope. IgG-C7 tetramers were formed by incubating IgG-C7 and protein $A$ at a 4:1 molar ratio in buffer $D$ for 1 hour at room temperature. The IgG-C7:protein A complexes were diluted in medium A to a final concentration of $20 \mu \mathrm{g} / \mathrm{ml}$ of antibody and processed as described above. Formation of the complexes was confirmed by blue native polyacrylamide gel electrophoresis. 
Heparinase treatment of primary hepatocytes. Primary hepatocytes were isolated as described (see above). Hepatocytes were incubated at $37^{\circ} \mathrm{C}$ for 1 hour with fresh DMEM medium containing $5 \%$ lipoprotein-deficient serum with or without $5 \mathrm{unit} / \mathrm{ml}$ heparinase (EC 4.2.2.7, Heparinase I; Sigma-Aldrich). DiI-labeled $\beta$-VLDL was added to the cells $(10 \mu \mathrm{g} / \mathrm{ml})$, and incubation at $37^{\circ} \mathrm{C}$ was continued for 2 hours. To test the activity of Heparinase I, $L d l r^{b / h} A r b^{+/+}$hepatocytes were incubated with apoE-enriched $\beta$-VLDL. Before the addition to the cells, the $\beta$-VLDL and apoE were incubated together $(5$ and $7.5 \mu \mathrm{g}$ of protein, respectively, unless otherwise indicated) for 1 hour at $37^{\circ} \mathrm{C}$. Human apoE3 was obtained as described (50). The cells were then washed with cold PBS, fixed with $4 \%$ PFA in buffer $\mathrm{F}(20 \mathrm{mM}$ sodium phosphate, $150 \mathrm{mM} \mathrm{NaCl}$, $2 \mathrm{mM} \mathrm{MgCl} 2)$ at $25^{\circ} \mathrm{C}$ for 5 minutes, and washed with PBS and water. Coverslips were mounted on slides and images were acquired using a DeltaVision RT deconvolution microscope running softWoRx Explorer Suite 1.1 (Applied Precision).

Statistics. The secretion rate of triglycerides and the half-lives of VLDL and LDL in $\mathrm{Arb}^{-/-}$and $\mathrm{Ldlr} /-$ mice were compared with those of wild-type animals using 2-sample, 2-tailed Student's $t$ test.

\section{Acknowledgments}

We thank Scott Clark, Clark Harris, and Debbie Morgan for excellent technical assistance. We thank Stephen Young and Loren Fong for the antibodies to apoB and helpful discussions. This study was funded by a grant from the NIH (HL-20948) and the Perot Family fund.

Received for publication June 16, 2006, and accepted in revised form October 10, 2006.

Address correspondence to: Helen H. Hobbs, Department of Molecular Genetics, 5325 Harry Hines Blvd., Dallas, Texas 753909064, USA. Phone: (214) 648-6724; Fax: (214) 648-7539; E-mail: helen.hobbs@utsouthwestern.edu. Or to: Jonathan C. Cohen, Center for Human Nutrition, 5325 Harry Hines Blvd., Dallas, Texas 75390-9064, USA. Phone: (214) 648-4774; Fax: (214) 648-7539; E-mail: jonathan.cohen@utsouthwestern.edu.

Christopher Jones and Rita Garuti contributed equally to this work.
1. Goldstein, J., Hobbs, H., and Brown, M. 2001. Familial hypercholesterolemia. In The metabolic and molecular bases of inherited disease. C. Scriver, A. Beaudet, W. Sly, and D. Valle, editors. McGraw-Hill. New York, New York, USA. 2863-2913.

2. Khachadurian, A.K., and Uthman, S.M. 1973. Experiences with the homozygous cases of familial hypercholesterolemia. A report of 52 patients. Nutr. Metab. 15:132-140.

3. Norman, D., et al. 1999. Characterization of a novel cellular defect in patients with phenotypic homozygous familial hypercholesterolemia. J. Clin. Invest. 104:619-628.

4. Zuliani, G., et al. 1995. Severe hypercholesterolaemia: unusual inheritance in an Italian pedigree. Eur. J. Clin. Invest. 25:322-331.

5. Harada-Shiba, M., et al. 1992. Siblings with normal LDL receptoractivity and severe hypercholesterolemia. Arterioscler. Thromb. 12:1071-1078.

6. Garcia, C.K., et al. 2001. Autosomal recessive hypercholesterolemia caused by mutations in a putative LDL receptor adaptor protein. Science. 292:1394-1398.

7. He, G., Gupta, S., Michaely, P., Hobbs, H.H., and Cohen, J.C. 2002. ARH is a modular adaptor protein that interacts with the LDL receptor, clathrin and AP-2. J. Biol. Chem. 277:44044-44049.

8. Mishra, S.K., Watkins, S.C., and Traub, L.M. 2002. The autosomal recessive hypercholesterolemia (ARH) protein interfaces directly with the clathrin-coat machinery. Proc. Natl. Acad. Sci. U. S. A. 99:16099-16104.

9. Mishra, S.K., et al. 2005. Functional dissection of an AP-2 beta 2 appendage-binding sequence within the autosomal recessive hypercholesterolemia (ARH) protein. J. Biol. Chem. 280:19270-19280.

10. Laporte, S.A., Miller, W.E., Kim, K.M., and Caron, M.G. 2002. beta-Arrestin/AP-2 interaction in G protein-coupled receptor internalization: identification of a beta-arrestin binging site in beta 2 adaptin. J. Biol. Chem. 277:9247-9254.

11. Garuti, R., et al. 2005. The modular adaptor protein autosomal recessive hypercholesterolemia (ARH) promotes low density lipoprotein receptor clustering into clathrin-coated pits. J. Biol. Chem. 280:40996-41004.

12. Zuliani, G., et al. 1999. Characterization of a new form of inherited hypercholesterolemia: familial recessive hypercholesterolemia. Arterioscler. Thromb. Vasc. Biol. 19:802-809.

13. Naoumova, R.P., et al. 2004. Autosomal recessive hypercholesterolaemia: long-term follow up and response to treatment. Atherosclerosis. 174:165-172.

14. Fellin, R., et al. 2003. Clinical and biochemical characterization of patients with autosomal recessive hypercholesterolemia (ARH). Nutr. Metab. Cardiovasc. Dis. 13:278-286.

15. Pisciotta, L., et al. 2006. Autosomal recessive hypercholesterolemia (ARH) and homozygous familial hypercholesterolemia (FH): a phenotypic comparison. Atherosclerosis. 188:398-405.

16. Arca, M., et al. 2002. Autosomal recessive hypercholesterolaemia in Sardinia, Italy, and mutations in ARH: a clinical and molecular genetic analysis. Lancet. 359:841-847.

17. Eden, E., Naoumova, R., Burden, J., McCarthy, M., and Soutar, A. 2001. Use of homozygosity mapping to identify a region on chromosome 1 bearing a defective gene that causes autosomal recessive homozygous hypercholesterolemia in two unrelated families. Am. J. Hum. Genet. 68:653-660.

18. Schmidt, H.H., et al. 1998. Delayed low density lipoprotein (LDL) catabolism despite a functional intact LDL-apolipoprotein B particle and LDLreceptor in a subject with clinical homozygous familial hypercholesterolemia. J. Clin. Endocrinol. Metab. 83:2167-2174.

19. Innerarity, T.L., and Mahley, R.W. 1978. Enhanced binding by cultured human fibroblasts of apo-Econtaining lipoproteins as compared with low density lipoproteins. Biochemistry. 17:1440-1447.

20. Jones, C., et al. 2003. Normal sorting but defective endocytosis of the low density lipoprotein receptor in mice with autosomal recessive hypercholesterolemia. J. Biol. Chem. 278:29024-29030.

21. Corsini, A., et al. 1992. Ability of the LDL receptor from several animal species to recognize the human apo B binding domain: studies with LDL from familial defective apo B-100. Atherosclerosis. 93:95-103.

22. Knouff, C., Malloy, S., Wilder, J., Altenburg, M.K., and Maeda, N. 2001. Doubling expression of the low density lipoprotein receptor by truncation of the 3 '-untranslated region sequence ameliorates type iii hyperlipoproteinemia in mice expressing the human apoe2 isoform. J. Biol. Chem. 276:3856-3862.

23. Mahley, R.W. 1988. Apolipoprotein E: cholesterol transport protein with expanding role in cell biology. Science. 240:622-630.

24. Beisiegel, U., Schneider, W.J., Goldstein, J.L., Anderson, R.G., and Brown, M.S. 1981. Monoclonal antibodies to the low density lipoprotein receptor as probes for study of receptor-mediated endocytosis and the genetics of familial hypercholesterolemia.

\section{J. Biol. Chem. 256:11923-11931.}

25. Pitas, R.E., Innerarity, T.L., and Mahley, R.W. 1980. Cell surface receptor binding of phospholipid: protein complexes containing different ratios of receptor-active and -inactive E apoprotein. J. Biol. Chem. 255:5454-5460.

26. Rohlmann, A., Gotthardt, M., Willnow, T.E., Hammer, R.E., and Herz, J. 1996. Sustained somatic gene inactivation by viral transfer of Cre recombinase. Nat. Biotechnol. 14:1562-1565.

27. Rohlmann, A., Gotthardt, M., Hammer, R.E., and Herz, J. 1998. Inducible inactivation of hepatic LRP gene by cre-mediated recombination confirms role of LRP in clearance of chylomicron remnants. J. Clin. Invest. 101:689-695.

28. Yakar, S., et al. 1999. Normal growth and development in the absence of hepatic insulin-like growth factor I. Proc. Natl. Acad. Sci. U. S. A. 96:7324-7329.

29. Horton, J.D., Shimano, H., Hamilton, R.L., Brown, M.S., and Goldstein, J.L. 1999. Disruption of LDL receptor gene in transgenic SREBP-1a mice unmasks hyperlipidemia resulting from production of lipid-rich VLDL. J. Clin. Invest. 103:1067-1076.

30. Harada-Shiba, M., et al. 2004. Disruption of autosomal recessive hypercholesterolemia gene shows different phenotype in vitro and in vivo. Circ. Res. 95:945-952.

31. Michaely, P., Li, W.P., Anderson, R.G., Cohen, J.C., and Hobbs, H.H. 2004. The modular adaptor protein ARH is required for low density lipoprotein (LDL) binding and internalization but not for LDL receptor clustering in coated pits. J. Biol. Chem. 279:34023-34031.

32. Strasser, V., et al. 2004. Receptor clustering is involved in Reelin signaling. Mol. Cell. Biol. 24:1378-1386.

33. Tabas, I., Lim, S., Xu, X.X., and Maxfield, F.R. 1990. Endocytosed beta-VLDL and LDL are delivered to different intracellular vesicles in mouse peritoneal macrophages. J. Cell Biol. 111:929-940.

34. Myers, J.N., Tabas, I., Jones, N.L., and Maxfield, F.R. 1993. Beta-very low density lipoprotein is sequestered in surface-connected tubules in mouse peritoneal macrophages. J. Cell Biol. 123:1389-1402.

35. Twisk, J., et al. 2000. The role of the LDL receptor in apolipoprotein B secretion. J. Clin. Invest. 105:521-532.

36. Millar, J.S., Cromley, D.A., McCoy, M.G., Rader, D.J., and Billheimer, J.T. 2005. Determining hepatic triglyceride production in mice: comparison of poloxamer 407 with Triton WR-1339. J. Lipid Res. 46:2023-2028.

37. Millar, J.S., Maugeais, C., Fuki, I.V., and Rader, D.J. 
2002. Normal production rate of apolipoprotein B in LDL receptor-deficient mice. Arterioscler. Thromb. Vasc. Biol. 22:989-994.

38. Shimano, H., et al. 1997. Elevated levels of SREBP-2 and cholesterol synthesis in livers of mice homozygous for a targeted distruption of the SREBP-1 gene. J. Clin. Invest. 100:2115-2124.

39. Yokode, M., Hammer, R.E., Ishibashi, S., Brown, M.S., and Goldstein, J.L. 1990. Diet-induced hypercholesterolemia in mice: prevention by overexpression of LDL receptors. Science. 250:1273-1275.

40. Butcher, E.C., and Lowry, O.H. 1976. Measurement of nanogram quantities of protein by hydrolysis followed by reaction with orthophthalaldehyde or determination of glutamate. Anal. Biochem. 76:502-523.

41. Goldstein, J.L., Basu, S.K., and Brown, M.S. 1983. Receptor-mediated endocytosis of low-density lipoprotein in cultured cells. Methods Enzymol. 98:241-260.

42. Kovanen, P.T., Brown, M.S., Basu, S.K., Bilheimer,
D.W., and Goldstein, J.L. 1981. Saturation and suppression of hepatic lipoprotein receptors: a mechanism for the hypercholesterolemia of cholesterol-fed rabbits. Proc. Natl. Acad. Sci. U. S. A. 78:1396-1400.

43. Perrey, S., et al. 2001. The LDL receptor is the major pathway for beta-VLDL uptake by mouse peritoneal macrophages. Atherosclerosis. 154:51-60.

44. Bolton, A.E., and Hunter, W.M. 1973. The labelling of proteins to high specific radioactivities by conjugation to a $125 \mathrm{I}$-containing acylating agent. Biochem. J. 133:529-539.

45. Krieger, M., et al. 1979. Reconstituted low density lipoprotein: a vehicle for the delivery of hydrophobic fluorescent probes to cells. J. Supramol. Struct. 10:467-478.

46. Pitas, R.E., Innerarity, T.L., Weinstein, J.N., and Mahley, R.W. 1981. Acetoacetylated lipoproteins used to distinguish fibroblasts from macrophages in vitro by fluorescence microscopy. Arteriosclerosis. 1:177-185.
47. Pathak, R.K., et al. 1990. Tissue-specific sorting of the human LDL receptor in polarized epithelia of transgenic mice. J. Cell Biol. 111:347-359.

48. Ishibashi, S., et al. 1993. Hypercholesterolemia in low density lipoprotein receptor knockout mice and its reversal by adenovirus-mediated gene delivery. J. Clin. Invest. 92:883-893.

49. Choi, S.Y., and Cooper, A.D. 1993. A comparison of the roles of the low density lipoprotein (LDL) receptor and the LDL receptor-related protein/ alpha 2-macroglobulin receptor in chylomicron remnant removal in the mouse in vivo. J. Biol. Chem. 268:15804-15811.

50. Bellosta, S., et al. 1995. Stable expression and secretion of apolipoproteins E3 and E4 in mouse neuroblastoma cells produces differential effects on neurite outgrowth. J. Biol. Chem. 270:27063-27071.

51. Imber, M.J., and Pizzo, S.V. 1981. Clearance and binding of two electrophoretic "fast" forms of human alpha 2-macroglobulin. J. Biol. Chem. 256:8134-8139. 